\title{
Influence of Maltodextrin on Physicochemical Characteristics of Lyophilized Mangaba Pulp
}

\author{
A. J. R. Barroso ${ }^{1}$, F. A. C. Almeida ${ }^{1}$, L. M. M. Silva ${ }^{1}$, D. S. Castro ${ }^{2} \&$ A. Figueiredo Neto ${ }^{3}$ \\ ${ }^{1}$ Department of Agricultural Engineering, Federal University of Campina Grande, Brazil \\ ${ }^{2}$ Department of Food, IFAL, Murici-AL, Brazil \\ ${ }^{3}$ Department of Agricultural Engineering, Federal University of San Francisco Valley, Brazil \\ Correspondence: A. Figueiredo Neto, Department of Agricultural Engineering, Federal University of San \\ Francisco Valley, Juazeiro, BA, Brazil. Tel: 55-2102-7621. E-mail: figueiredoacacio@gmail.com
}

Received: August 20, 2017

Accepted: October 2, $2017 \quad$ Online Published: October 15, 2017

doi:10.5539/jas.v9n11p253

URL: https://doi.org/10.5539/jas.v9n11p253

The research is financed by $C N P q$.

\begin{abstract}
The use of lyophilization has increased because of the quality attributes exhibited by dehydrated products, which can be directly consumed or added in formulations of high nutritional value. The objective of this study was to obtain mangaba powder through the lyophilization of the formulations F1 - 0\%, F2 - 10\%, F3 - 20\% and F4 $30 \%$, chosen based on the percentage of the carrier agent, for the characterization of its water content, titratable acidity, $\mathrm{pH}$ and color, represented by the parameters luminosity $\left(\mathrm{L}^{*}\right)$, intensity of red $\left(+\mathrm{a}^{*}\right)$ and intensity of yellow $\left(+b^{*}\right)$. The results showed that the addition of maltodextrin positively altered the characteristics of the product, favoring a reduction in the parameters of acidity (5.36 to 1.5), $\mathrm{pH}$ (3.71 to 4.13), water activity (0.230 to 0.075 ) and moisture (11.44 to 1.16 ), as well as an increase in luminosity $\mathrm{L}^{*}$, which varied from 52.16 to 72.5 , and reduction in the chromaticity $\mathrm{a}^{*}$ and $\mathrm{b}^{*}$, showing results that express a lower intensity of red and yellow colors, approaching zero for $\mathrm{a}^{*}$ and $\mathrm{b}^{*}$, respectively, and also that the production of mangaba powder can be a viable alternative for its industrialization and a choice for the development of the crop with generation of employment and income to farmers.
\end{abstract}

Keywords: carrier agent, powder extract, Hancornia speciosa Gomes, drying

\section{Introduction}

Since its beginning, globalization has promoted various changes in the daily life of society, particularly in the form of eating, which has currently ceased to be a physiological need and has become a determinant factor for the maintenance of health, leading industries to develop new products that can meet the organoleptic and nutritional requirements of the consumer, who is increasingly more demanding with respect to food, observing the quality regarding attributes of healthy, safe, attractive and practical food (López-Patiño, 2011; Sorzano, 2015).

This new reality of the 21 st century brings many challenges to food industries, which are stimulated to promote technological innovation to be able to meet the new demands, using the combination of groups of foods in order to reinforce sensory and nutritional attributes, and calling attention to their richness in bioactive compounds and nutraceutical potential (Remberg et al., 2007; Milivojevic et al., 2013).

Hancornia speciosa is an exotic fruit from the Brazilian Cerrado with great potential for the development of products and, consequently, it can be used in human food and generate income. Studies have demonstrated that presents a high antioxidant activity (Rufino et al., 2009, 2010) and, therefore, its consumption can reduce the incidence of heart and brain diseases and cancer. The antioxidant activity can be mainly associated with the presence of innumerous bioactive compounds, including carotenoids, vitamin C, vitamin E and folates (Valko et al., 2007).

The highest mangaba production occurs in the states of the Brazilian Northeast region, where the crop has great economic potential due to the quality of its fruits, which are consumed fresh or used in the production of juices, 
candies and ice creams (Moura et al., 2011). In addition, its industrialization can allow the consumption along the entire year, promoting a new alternative for the Brazilian agro-industry.

Aiming at new trends of the market, the use of lyophilization becomes an ally in the elaboration of products that meet nutritional and quality needs for food production. This technique increases the shelf life and promotes minimum alterations in the foods with respect to nutritional and sensory aspects, since it retains from 80 to $100 \%$ of volatile and aromatic compounds (Cleef et al., 2010), also lowering the water activity in the food, creating a barrier against the development of microorganisms. It reduces food density with little loss of nutrients and allows rapid and complete dehydration due its the porous structure (Evangelista, 2005; Fellows, 2008; Cleef et al., 2010).

Thus, production techniques use to characterize the most varied fruits produced in the country, as well as the various forms of commercialization of their derivatives, is essential to stimulate production and consumption incentive programs, besides adding value and promoting opportunity to small producers.

In this context, there are few studies on mangaba powder. In the literature, there are the studies of Chaves et al. (2009), on the kinetics of lyophilization, and Santos et al. (2012), on the physicochemical evaluation. As mentioned above, the scene is critical and studies using lyophilization for the use of this product by the industry are rare. Thus, this study aimed to evaluate the influence of maltodextrin on the physicochemical characteristics and color of lyophilized mangaba pulp.

\section{Materials and Methods}

The experiments were carried out at the Laboratory of Storage and Processing of Agricultural Products (LAPPA) of the Academic Unit of Agricultural Engineering of the Federal University of Campina Grande (UFCG), Campina Grande-PB, Brazil, and the raw material came from the region of João Pessoa-PB, acquired in 100-g packages with mean moisture of $90 \%$ and $8{ }^{\circ}$ Brix.

Four formulations were prepared taking into account the pulp content to calculate the consideration the concentration of the carrier agent (maltodextrin Dextrose Equivalent 20), F1 - 0\%, F2 - 10\%, F3 - 20\% and F4 $-30 \%$. These formulations were stored in plastic shape and stored in a freezer $\left(-18{ }^{\circ} \mathrm{C}\right)$ for $72 \mathrm{~h}$. After freezing, the material was arranged on trays and subjected to lyophilization (model LioTop L101 manufacturer Liobras, Brazil) at temperature of $-50 \pm 3{ }^{\circ} \mathrm{C}$ under vacuum $(90-130 \mu \mathrm{Hg})$ for $72 \mathrm{~h}$. Then, the lyophilized materials were ground in a blender (Arno - Model ClicLav Top) with filter and stored under ambient temperature $\left(82.4{ }^{\circ} \mathrm{F}\right)$ in flexible packages of laminated polyethylene until analyses.

To obtain the data, the experiment and the analyses were performed in triplicates. The lyophilized pulps were characterized for the following parameters:

Water content - obtained through the method of drying of the samples in an oven at $105^{\circ} \mathrm{C}$ until constant weight, according to methodology $\mathrm{n}^{\circ} .926 .08$ of the AOAC (1997).

Titratable acidity - determined through the titration of the sample with $0.1 \mathrm{~N}$ sodium hydroxide solution, using $1 \%$ phenolphthalein as indicator, with results expressed in grams of citric acid/100 g of the sample, according to methodology of the AOAC (2007).

$\mathrm{pH}$ - determined through the potentiometric method in a potentiometer (MS Tecnopar), previously calibrated with buffer solutions of $\mathrm{pH} 7.0$ and $\mathrm{pH} 4.0$ at temperature of $20^{\circ} \mathrm{C}$.

Water activity (AW) - determined through the direct reading of the sample at temperature of $25^{\circ} \mathrm{C}$, in a hygrometer (Aqualab, model 3TE-B, Decagon Devices), which uses the dew-point principle, according to which water is condensed on mirrored and cold surface, and detected by an infrared sensor.

Color - The instrumental color was determined through reflectance of the system of rectangular coordinates using a colorimeter (MiniScan XE PLUS, model MSXP - 4500L), based on the CIELAB system, in which the color is measured through the color parameters $\mathrm{L}^{*}=$ luminosity $(0=$ black and $100=$ white $)$; $\mathrm{a}^{*}(-80$ to $0=$ green, 0 to $+100=$ red $)$ and $b^{*}(-100$ to $0=$ blue, 0 to $+70=$ yellow $)$, with illuminant D65.

The data obtained experimentally was statistically analyzed and the means were compared by Tukey test, using the computational program ASSISTAT, version 7.7 (Silva \& Azevedo, 2016).

\section{Results and Discussion}

Table 1 shows the results of acidity, $\mathrm{pH}$, moisture and water activity of the studied formulations of lyophilized mangaba. For the determination of acidity, there was significant difference between the formulations and the result obtained for F1 (5.29 g/100 g) was statistically superior to those of the other concentrations, which 
decreased with the increase of maltodextrin. The high acidity in F1 can be explained by the reduction of water content along the drying process and consequent concentration of the acids present in the pulp, as evidenced by the reductions of acidity as the percentage of maltodextrin increased in the formulations (F1 $>$ F2 $>$ F3 $>F 4$ ) and, also, due to the decrease in the suspension of the compounds present in the final product. These results are consistent with those obtained by Chaves et al. (2009), who worked with lyophilized mangaba using $17 \%$ of maltodextrin and found acidity of $1.5 \mathrm{~g} / 100 \mathrm{~g}$, and partially with those of Cardoso and Reis (2014), who studied fresh mangaba and observed acidity of $0.8 \mathrm{~g} / 100 \mathrm{~g}$.

Table 1. Mean values of physicochemical characteristics of mangaba powder

\begin{tabular}{lllllll}
\hline \multirow{2}{*}{ Parameters } & \multicolumn{3}{c}{ Concentration of Maltodextrin } & \multirow{2}{*}{ LSD } & \multirow{2}{*}{ CV $(\%)$} \\
\cline { 2 - 6 } & F1 & F2 & F3 & F4 & & \\
\hline Acidity (g/100 g of citric acid) & $5.29^{\mathrm{a}}$ & $3.00^{\mathrm{b}}$ & $2.05^{\mathrm{c}}$ & $1.52^{\mathrm{d}}$ & 0.38 & 4.91 \\
$\mathrm{pH}$ & $3.70^{\mathrm{d}}$ & $3.83^{\mathrm{c}}$ & $4.01^{\mathrm{b}}$ & $4.12^{\mathrm{a}}$ & 0.05 & 0.45 \\
Moisture (\%) & $11.44^{\mathrm{a}}$ & $4.80^{\mathrm{b}}$ & $2.11^{\mathrm{c}}$ & $1.22^{\mathrm{d}}$ & 0.72 & 5.62 \\
Water activity & $0.230^{\mathrm{a}}$ & $0.218^{\mathrm{a}}$ & $0.096^{\mathrm{b}}$ & $0.075^{\mathrm{c}}$ & 0.01 & 2.99 \\
\hline
\end{tabular}

Note. Means followed by the same letter in the row do not differ statistically by Tukey's test at 0.05 probability level. LSD: Least significant difference; CV: Coefficient of variation.

For the determination of $\mathrm{pH}$, the results were contrary to those of acidity; however, in practice, the numbers interfere with the organoleptic perception of the product. Hence, there was significant statistical difference between the formulations and F4 (4.12) exhibited the highest $\mathrm{pH}$ value. The difference between the studied formulations is directly related to the addition of the adjuvant, which can be observed in Table 1 and in studies conducted by authors such as Chaves et al. (2009) and Santos et al. (2012), who studied physicochemical characteristics of lyophilized mangaba and found results of 4.7 and 3.01, respectively, for this parameter, which led to the conclusion that, besides the origin of the raw material, the addition of drying adjuvant also promotes significant alterations in the physicochemical quality of the obtained powder.

Acidity and $\mathrm{pH}$ are two inversely proportional parameters that have influence on the sensory quality of the product, besides being a microbiological quality indicator in the specific case of $\mathrm{pH}$, since bacteria have an optimal range for development. Thus, the formulations showed values below the minimum $\mathrm{pH}$ range for the development of most bacteria, which suggests that it is a good indicator for storage, promoting longer shelf life.

The obtained data show improvement in these two parameters and indicate the importance of using a carrier agent, considering that the production of mangaba powder in the formulation F1, in the present study, showed moisture percentage above $5 \%$, which is outside the standard required by the legislation for lyophilized fruits, unlike the other studied concentrations, which showed lower moisture content, meeting the specifications of the Brazilian legislation.

It is known that drying favors the reduction of moisture content, which leads to the alteration of AW and, consequently, promotes reduction in the perishability of the product. The percentages determined in the present study, except for F1, are within the standards of the legislation and statistically different; thus, maltodextrin is a determinant factor for the promotion of this alteration. Hence, in F2 formulation it is possible to observe that there was a reduction of more than $41 \%$ in the moisture content, in comparison to $\mathrm{F} 1$.

Chaves et al. (2009) and Santos et al. (2012) determined moisture percentages in lyophilized mangaba of 20.69\% and $23.1 \%$, respectively, which are higher than four times the limit established by Brasil Food Legislation (1978). Therefore, the products obtained under these conditions by the above-mentioned authors are classified as non-conform with the standards for lyophilized fruits.

The AW indicates the amount of water available to perform the molecular movement and its transformations and promote microbial growth in the product (Zambrano et al., 2005). Thus, the values in Table 1 for AW are within the requirements of the legislation, varying from 0.075 to 0.230 , which are much lower than the minimum indicated in the literature for the development of microorganisms. The values found here showed significant difference between the formulations when drying adjuvant is added (F2 $>$ F3 $>$ F4), but did not show difference between F1 and F2. It is possible to observe that this difference is directly related to the concentration of the adjuvant, because the drying time was the same for all. According to Fellows (2006), water activity values lower than 0.6 are stable from the microbiological point of view and indicate that there will be no growth of 
deteriorating or pathogenic microorganisms under these conditions. Thus, the obtained results of AW allow to ensure the microbiological quality of the product, since the values of Table 1 are up to 8 times lower than 0.6 .

Table 2 shows the means for color $\left(\mathrm{L}^{*}, \mathrm{a}^{*}\right.$ and $\left.\mathrm{b}^{*}\right)$. These parameters allow to evaluate the alterations in the color of the product and can be used as standards of quality and even identification of the presence of substances in the foods, based on their intensity, such as the presence of dyes and other substances that can increase or decrease the values of color.

Table 2. Mean values of color of the formulations

\begin{tabular}{|c|c|c|c|c|c|c|}
\hline \multirow{2}{*}{ Parameters } & \multicolumn{4}{|c|}{ Concentration of Maltodextrin } & \multirow{2}{*}{ LSD } & \multirow{2}{*}{ CV $(\%)$} \\
\hline & F1 & $\mathrm{F} 2$ & F3 & F4 & & \\
\hline $\mathrm{L}^{*}$ & $52.16^{\mathrm{d}}$ & $62.27^{\mathrm{c}}$ & $67.46^{\mathrm{b}}$ & $72.50^{\mathrm{a}}$ & 0.54 & 0.40 \\
\hline$a^{*}$ & $9.26^{\mathrm{a}}$ & $5.61^{\mathrm{b}}$ & $3.86^{\mathrm{c}}$ & $2.68^{\mathrm{d}}$ & 0.25 & 2.21 \\
\hline$b^{*}$ & $31.49^{\mathrm{a}}$ & $29.37^{\mathrm{b}}$ & $26.24^{\mathrm{c}}$ & $26.63^{\mathrm{d}}$ & 0.91 & 1.56 \\
\hline
\end{tabular}

Note. Means followed by the same letter do not differ statistically by Tukey's test at 0.05 probability level. LSD: Least significant difference; CV: Coefficient of variation.

In the analysis of color, there was significant difference for all parameters. There was a positive variation in luminosity for the formulations mixed with adjuvant, reaching $39.9 \%$ in comparison to F1 - $0 \%$ of adjuvant. This trend for $\left(\mathrm{L}^{*}=\right.$ white $)$ is due to the low moisture content and increase in the concentration of maltodextrin, which is a white product and, when mixed with others of different colors, makes them lighter, due to the dilution of the pigmentation of the raw material. A similar behavior for this parameter was also observed by Tonon et al. (2009), with a greater increase (19.79\%) in the final product, and by Oliveira et al. (2014), who found 7.31\%, performing the drying of juice and pulp with the addition of adjuvant.

The chromaticity a* showed negative variation from 39.42 to $71.06 \%$ in the slightly reddish tonality, with a trend of reduction to slightly greenish, as the concentration of the adjuvant increased. Santos et al. (2015) also observed this behavior analyzing cashew pulp powder with $10 \%$ of maltodextrin. For the chromaticity $b^{*}$, there was not a large variation in the yellow intensity, which decreased by up to $16.67 \%$, indicating a reduction in the tonality of yellow. This behavior of reduction in the coordinates $a^{*}$ and $b^{*}$ was also observed by Tonon et al. (2009), who lyophilized fruit added of maltodextrin.

Thus, the use of a carrier agent and its direct relation with the drying time is very important to obtain a quality powder, as well as to obtain results that meet the legislation, besides having direct influence on the yield of the process.

\section{Conclusions}

The use of maltodextrin in mangaba lyophilization promoted significant alterations in the final product, favoring the improvement of physicochemical characteristics. The moisture content remained within the range specified in the legislation for lyophilized fruits; there was decrease in acidity and increase in $\mathrm{pH}$, as a function of the studied concentrations, and the water activity in the final product allows to infer that there will be no microbial development and its microbiological quality will be maintained. The application of new technologies for mangaba processing and to obtain powder extract reduces post-harvest losses, thus becoming a viable alternative for a greater use of this fruit.

\section{References}

AOAC (Association of Official Analytical Chemists International). (1997). Official methods of analysis of Association of Official Analytical Chemists (17th ed.). Washington: AOAC.

AOAC (Association of Official Analytical Chemists International). (2007). Official methods of analysis of Association of Official Analytical Chemists (18th ed.). Gaithersburg: AOAC.

Brasil Food Legislation. (1978). Resolução $n^{\circ} 12$, de 24 de julho de 1978 da Comissão Nacional de Normas e Padrões para Alimentos. Ministério da Saúde. Agência Nacional de Vigilância Sanitária. Diário Oficial da União; Poder Executivo.

Cardoso, L. D. M., \& Reis, B. D. L. (2014). Mangaba (Hancornia speciosa Gomes) from the Brazilian Cerrado: nutritional value, carotenoids and antioxidant vitamins. Fruits-Journal, Paris, 69, 89-99. https://doi.org/ $10.1051 /$ fruits/2013105 
Chaves, A. S., et al. (2001). Liofilização da polpa de mangaba para obtenção da fruta em pó. VI Congresso de Iniciação Cientifica da Universidade Federal de Campina Grande, Campina Grande, 2009. Anais do VI Congresso de Iniciação Cientifica da Universidade Federal de Campina Grande, Artigo.

Cleef, E. H. C. B. V., Ezequiel, J. M. B., Gonçalves, J. D. S., \& Pascoal, L. A. F. (2010). Dry matter determination of sheep feces and chicken chest meat with the traditional method and freeze drying. Revista Veterinária, Málaga, 11(4), 01-10.

Evangelista, J. (2005). Tecnologia de alimentos (2nd ed., p. 652). São Paulo: Atheneu.

Fellows, P. J. (2006). Tecnologia do processamento de alimentos: princípios e prática (1st ed., p. 602). Porto Alegre: Artmed.

Ferreira, E. F., Marinho, S. J. O. (2007). Produção de frutos da mangabeira para consumo in natura e industrialização. Tecnologia \& Ciência Agropecuária, João Pessoa, 1(1), 9-14.

Lopez-Patino, C. L. (2011). Globalización y producción de propóleos (Propolis de Apis Mellifera) en Colombia y América Latina. Biotecnología en el Sector Agropecuario y Agroindustrial, 9(1), 119-125.

Milivojevic, J., Rakonjac, V., Akšić, M. F., Pristov, J. B., \& Maksimović, V. (2013). Classification and fingerprinting of different berries based on biochemical profiling and antioxidant capacity. Pesquisa Agropecuária Brasileira, Brasília, 48(9), 1285-1294. https://doi.org/10.1590/S0100-204X2013000900013

Moura, N. F., Chaves, L. J., Venkovsky, R., Naves, R. V., Aguiar, A. V., \& Moura, M. F. (2011). Genetic structure of mangaba (Hancornia speciosa Gomes) populations in the Cerrado region of central Brazil. Bioscience Journal, 27(3), 473-481.

Oliveira, G. S., Costa, J. M. C., \& Afonso, M. R. A. (2014). Characterization and hygroscopic behavior of lyophilized yellow mombin in pulp powder. Revista Brasileira de Engenharia Agrícola e Ambiental, Campina Grande, 18(10), 1059-1064. https://doi.org/10.1590/1807-1929/agriambi.v18n10p1059-1064

Remberg, S. F., Mage, F., Haffner, K., \& Blomhoff, R. (2007). Highbush blueberries Vaccinium corymbosum L., framboesas Rubus idaeus L. e groselhas pretas Ribes nigrum L.- Influência da cultivar na atividade antioxidante e outros parâmetros de qualidade. Acta Horticulturae, 744, 259-266. https://doi.org/10.17660/ ActaHortic.2007.744.27

Rufino, M. S. M., Fabiano, A. N. F., Ricardo, E. A., \& Edy, S. de B. (2009). Free radical-scavenging behaviour of some north-east Brazilian fruits in a DPPH system. Food Chemistry, Kidlington, 114(2), 693-695. https://doi.org/10.1016/j.foodchem.2008.09.098

Rufino, M. S. M., Ricardo, E. A., Edy, S. de B., Jara, P.-J., Fulgencio, S.-C., \& Jorge, M.-F. (2010). Bioactive compounds and antioxidant capacities of 18 non-traditional tropical fruits from Brazil. Food Chemistry, Kidlington, 121(4), 996-1002. https://doi.org/10.1016/j.foodchem.2010.01.037

Santos, D. C., et al. (2015). Drying of cashew pulp in spouted bed dryer. Revista Brasileira de Tecnologia Agroindustrial, Curitiba, 9(2), 1875-1887.

Santos, J. T. S., et al. (2012). Lyophilized mangaba assessment by physical and chemical parameters. Scientia Plena, Aracaju, 8(3), 1-5.

SEBRAE (Serviço de Apoio às Micro e Pequenas Empresas). (2016). Sistema de inteligência de mercado. Agronegócio: Fruticultura. Boletim de inteligência, Outubro/2015, 5 páginas. Retrieved September 20, 2016, from http://www.sebraemercados.com.br/fruticultura

Sorzano, A. H. (2015). La soberanía alimentaria desde la agricultura urbana: Un reto para el desarrollo de la producción de alimentos en cuba. Revista Geonordeste, São Cristóvão, Ano XXVI, 1, 150-172.

Tonon, R. V., Brabet, C., \& Hubinger, M. D. (2009). Influence of drying air temperature and carrier agent concentration on the physicochemical properties of açai juice powder. Ciência e Tecnologia de Alimentos, Campinas, 29(2), 444-450. https://doi.org/10.1590/S0101-20612009000200034

Valko, M., Dieter, L., Jan, M., Mark, T. D. C., Milan, M., \& Joshua, T. (2007). Free radicals and antioxidants in normal physiological functions and human disease. The International Journal of Biochemistry \& Cell Biology, Amsterdam, 39, 44-84. https://doi.org/10.1016/j.biocel.2006.07.001

Vieira, R. F. (2010). Frutas nativas da região Centro-Oeste (p. 322). EMBRAPA, Brasília. 
Zambrano, F., Hikage, A., Cássia, R. D., Ormenese, C., \& Montenegro, F. M. (2005). Effect of Guar and Xanthan Gums as Fat Substitutes in Industrially Produced Cakes. Brazilian Journal of Food Technology, Campinas, 8(1), 63-71.

\section{Copyrights}

Copyright for this article is retained by the author(s), with first publication rights granted to the journal.

This is an open-access article distributed under the terms and conditions of the Creative Commons Attribution license (http://creativecommons.org/licenses/by/4.0/). 